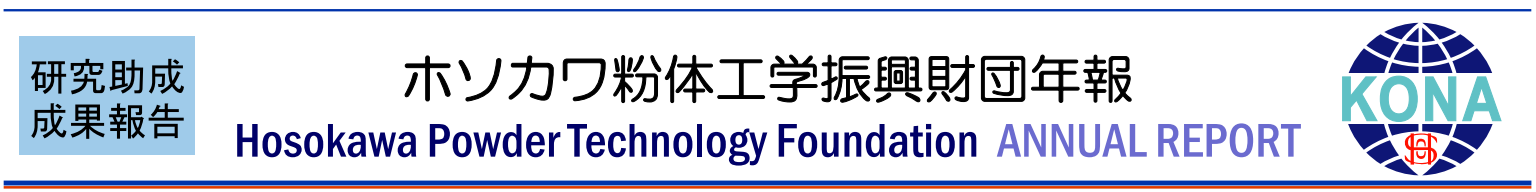

13122

\title{
高活性触媒白金ナノ粒子の精密合成法の確立 \\ Precise Synthesis of High Active Catalytic Pt Nanoparticles
}

研究代表者 Research leader：根岸 雄一 Yuichi NEGISHI

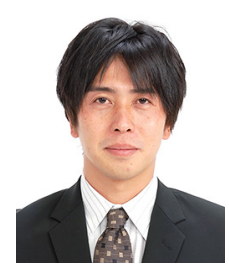

東京理科大学理学部 准教授

Faculty of Science, Tokyo University of Science, Associate Professor

E-mail: negishi@rs.kagu.tus.ac.jp

\section{抄録}

本研究では，高い酸素還元触媒能を有する新規白金クラスターの合成に取り組んだ。配位子にはテ トラオクチルアンモニウムブロミドとフェニルエタンチオラートを用い，クラスター合成にはポリ オール還元法を用いた，その結果，反応時間という非常に単純なパラメーターを調節することで， 様々なサイズの白金クラスターをサイズ選択的に合成することに成功した．また，配位子にフェニ ルエタンチオラートを用いた際，最小の白金クラスター中には白金が 54-57 原子，硫黄が 12-16 原 子含まれていることが MALDI 質量分析より明らかになった。このようにして合成した白金クラス ターを用いて電極を作成し, 白金クラスターの酸素還元触媒能について調べたところ, 白金クラス ターを用いると，市販の白金ナノ粒子を用いた場合よりも活性が約 1.5 倍程度向上することが分 かった.

\begin{abstract}
In this work, we attempted to synthesize the novel small platinum cluster via common ligand (tetraoctylammonium and phenylethanethiolate) and polyol reduction procedure. Then, some clusters were synthesized size-selectively by modulating the simple parameters, i.e. reaction time. MALDI analysis revealed that minimum phenylethanethiolate protected platinum cluster contained 54-57 platinum atoms and 12-16 sulfur atoms. Finally, we tested catalytic activity of oxygen reduction regarding obtained clusters. The results indicated that the catalytic activity of small cluster is about 1.5 times higher than that of conventional platinum nanoparticle.
\end{abstract}

\section{研究背景と目的}

エネルギー資源の有効利用と地球環境保全は 現在, 人類に課せられた大きな緊急課題である。 燃料電池（図 1) は物質が持つ化学エネルギー を電気エネルギーに直接変換する発電装置であ
り, 火力発電などの熱機関に比べて効率が高く 環境にも優しい。 なかでも，固体高分子型燃料 電池は小型軽量で原理的に高出力密度化や低コ スト化が可能であるため, 電気と熱を併給する 家庭用据え置き用途, 燃料電池自動車や移動・ 携带用電源として大きな注目を集めており，現 
Fuel cell

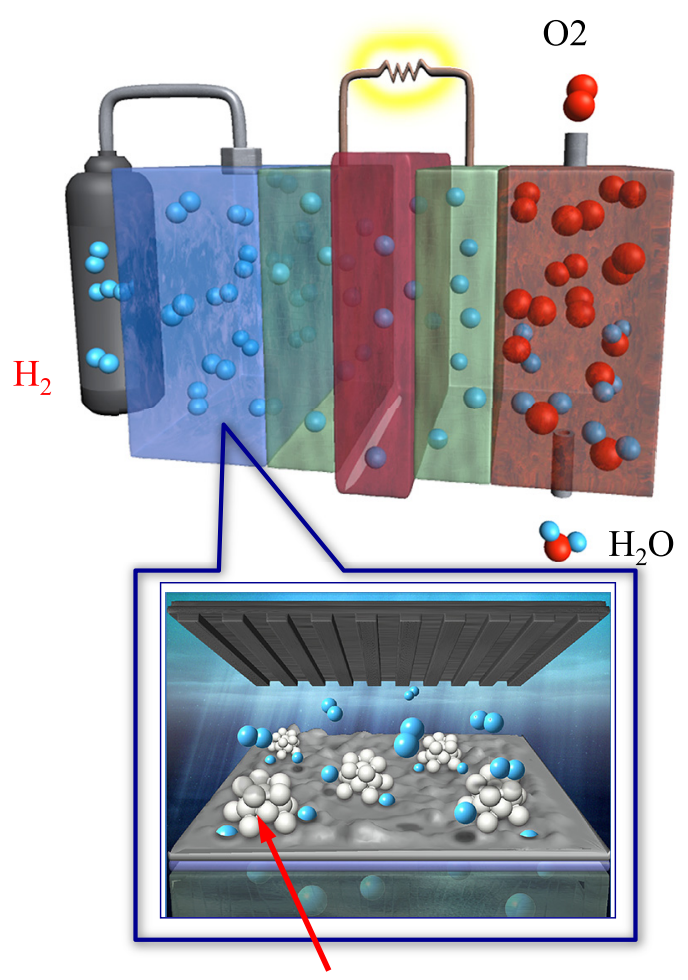

Pt cluster

Figure 1 Fuel cell and role of Pt cluster.

在，世界的な研究・開発競争が繰り広げられて いる。実際，エネファーム，レジャー用電源だ けではなく，燃料電池自動車についてもすでに 実用化が始まっている。しかしながら，自動車 用，家庭用の燃料電池がエネルギー・環境問題 の真の救世主となるためには, 現在のシステム を改良, 量産化対応と併せて, 電極材料, 電解 質膜, 及び周辺部材に扔ける “革新的な新材料” 開発を行い, 一層の高性能化，低コスト化を図 ることが必須である。

現在，燃料電池の電極材料としては，白金が 広く利用されている（図 1).しかしながら， 白金は極めて高価な貴金属であるため, 燃料電 池のコスト低減には触媒活性を向上させ，その 使用量を極限まで抑えることが重要な課題と なっている．白金を微粒子化することは，その 有効な手段の一つである. 粒径 $2 \sim 4 \mathrm{~nm}$ の白 金微粒子を電極材料に用いると, 反応に寄与す る表面積の割合が増加し, 触媒効率が高まる。
そのため,こうしたサイズの白金微粒子が電極 材料として用いられている。東工大のグループ は, 独自に開発した特殊な球状高分子を用いて, 更にサイズの小さな $1 \mathrm{~nm}$ 程度のサイズ領域で, 粒径が制御された白金クラスターを精密かつ系 統的に合成することに成功しており，これらの 白金クラスターは, 粒径 $2 \sim 4 \mathrm{~nm}$ の白金微粒 子よりも高い酸素還元触媒能を有することを明 らかにした（Yamamoto K. et al., 2009）。このこ とは, 粒径 $1 \mathrm{~nm}$ 程度の白金クラスターを燃料 電池の電極材料に応用した場合, 従来の白金触 媒を用いた場合よりも, 効率的に電流を取り出 すことが可能であることを示している.一方で, 彼らの合成法では特殊な高分子の使用が不可欠 であるため, 他の研究グループが同じ白金クラ スターを合成することは極めて難しいことが問 題点として挙げられる。 そのため, こうしたサ イズの白金クラスターを実際に燃料電池へと応 用するためには，簡便な方法にて白金クラス ターを合成することが必要である。また，合成 した白金クラスターの化学組成を厳密に決定す ることが出来れば, サイズだけではなく, 構成 原子数と触媒活性との相関についても明らかに することが可能となる. 本研究ではこうした研 究背景の下, 簡便な方法にて, 高活性な酸素還 元触媒能を有する白金クラスターの新規精密合 成法の確立を目指した。

\section{研 究 方 法}

\section{1 テトラオクチルアンモニウムブロミド保 護白金クラスターの合成}

白金クラスターの合成には, 市販の有機分子 であるテトラオクチルアンモニウムブロミド $\left(\mathrm{C}_{32} \mathrm{H}_{68} \mathrm{BrN}\right)$ （図 2 (a)）と, 溶媒（エチレン グリコール）の還元力を利用したポリオール還 元法を用いた（Wang Y. et al., 2000）。まず, $0.20 \mathrm{mmol}$ の塩化白金酸をエチレングリコール 溶液に溶解させた。この溶液に水酸化ナトリウ

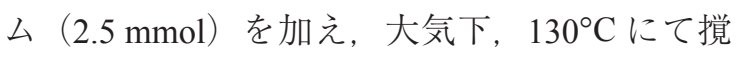
拌し続け (30 分, 1 時間, 2 時間), 得られた 
(a)
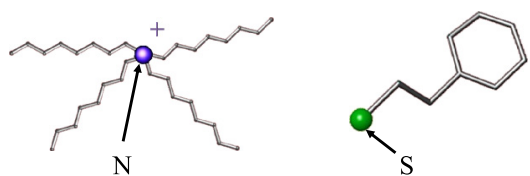

Figure 2 Ligands used for synthesis; (a) tetraoctylammonium ion, (b) phenylethanethiolate.

黒褐色の溶液に配位子となるテトラオクチルア ンモニウムブロミド $(0.20 \mathrm{mmol})$ とトルエン の混合溶媒を徐々に加えた。混合溶媒を全て加 えた後，常温にて 30 分間擋拌し続けた。この 溶液に超純水を加え, 溶液を二相に完全に分離 させた後, 有機相を分取し, 超純水によってエ チレングリコール，未反応の塩化白金酸を取り 除いた。真空乾燥後, メ夕ノールを加えること で過剰のテトラオクチルアンモニウムブロミド を洗浄し，テトラオクチルアンモニウムブロミ ド保護白金クラスターを得た。

2 フェニルエタンチオラート保護白金クラ スターの合成

フェニルエタンチオラート $\left(\mathrm{C}_{2} \mathrm{H}_{4} \mathrm{PhS}\right)$ （図 2 (b)）保護白金クラスターについても，テトラ オクチルアンモニウムブロミド保護白金クラス ターと同様の方法を用いた（Wang Y. et al., 2000)。変更したのは，配位子にフェニルエタ ンチオール $\left(\mathrm{C}_{2} \mathrm{H}_{4} \mathrm{PhSH}\right)$ を $4.0 \mathrm{mmol}$ を使用し た点である。

\section{3 白金クラスターの評価}

合成した白金クラスターの粒系について調べ るために, 透過型電子顕微鏡 (TEM) 観測を行っ た。また，クラスターの化学組成について調べ るために，マトリックス支援レーザー脱離イオ ン化（MALDI）質量スペクトルを測定した (Murray R. W. et al., 2008).

\section{4 酸素還元触媒能の評価}

合成した白金クラスターをカーボン上に吸着 させて，白金クラスター修飾電極を作成した。

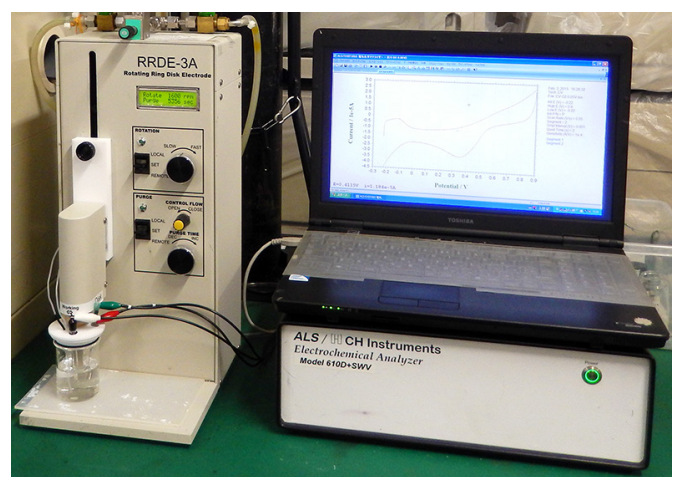

Figure 3 Instrument used for this work.

その後, 回転デイスクボルタンメトリー（図 3) により得られた電流值から，Koutecky-Levich 式 （式 1）を用いて白金クラスター修飾電極の質 量活性を求め, 酸素還元触媒能について調べた.

$\frac{1}{I}=\frac{1}{I_{\mathrm{k}}}+\frac{1}{I_{\lim }} \frac{1}{\omega^{1 / 2}}$

ここで $I_{\mathrm{k}}$ は活性化支配電流， $I_{\mathrm{lim}}$ は限界電流， ）は回転数である.

研究成果

1 テトラオクチルアンモニウムブロミド保 護白金クラスターの合成と評価

図 4 に, 反応時間 30 分にて合成したテトラ オクチルアンモニウムブロミド保護白金クラス ターの TEM 像を示す. 粒径約 $1 \mathrm{~nm}$ の粒子が 観測され，粒径分布も狭いことが確認された。 このことは，本実験手法を用いることで，目的 のサイズの白金クラスターが合成されたことを
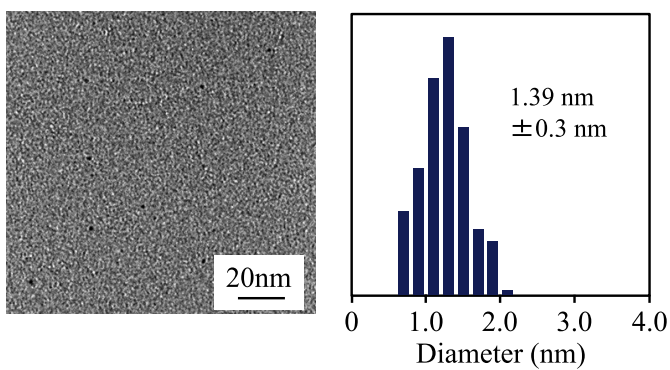

Figure 4 TEM of tetraoctylammonium protected Pt cluster. 


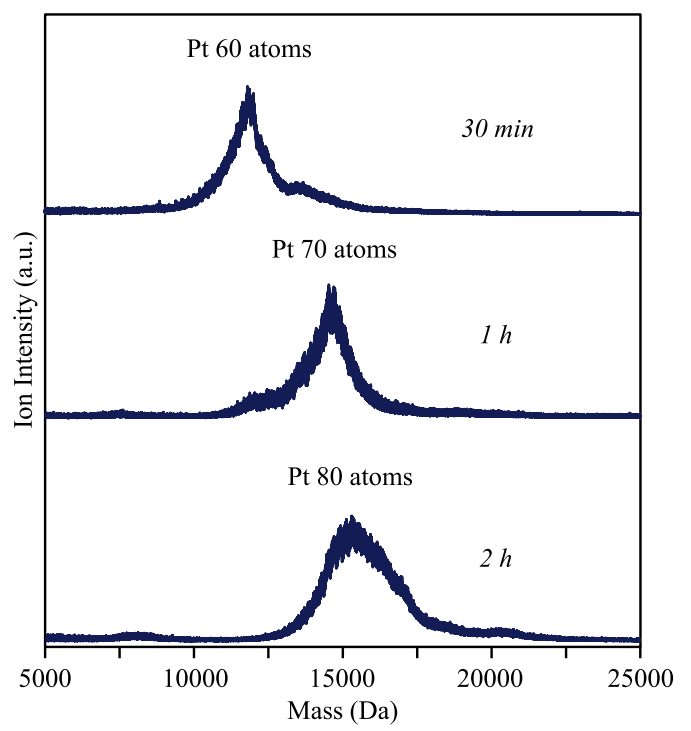

Figure 5 MALDI mass spectra of tetraoctylammonium protected Pt cluster.

示している.

こうして合成されたテトラオクチルアンモニ ウムブロミド保護白金クラスターの化学組成に ついて決定するため, MALDI 質量スペクトル の測定を行った，過去の研究より，MALDI 質 量分析が様々な有機配位子保護金属クラスター の化学組成を決定する上で, 非常に有効な手段 であることが明らかにされている（Negishi Y. et al., 2012a, 2012b, 2013, 2014, Jin R. et al., 2012). MALDI 質量分析とは, 目的物質とマト リックスを混合し, 特定の波長のレーザー光を 照射することで, 目的物質を非破壊の状態でイ オン化する方法である. 図 5 に反応時間を 30 分, 1 時間， 2 時間として合成した白金クラスター の MALDI 質量スペクトルを示す。スペクトル 中には, $12 \mathrm{kDa}, 14 \mathrm{kDa}, 16 \mathrm{kDa}$ の位置にブロー ドな 1 本のピークが観測され，これらのクラス ターはそれぞれ，白金約 60 原子， 70 原子， 80 原子から構成されていることが分かった。この ことは反応時間を長くすることで，粒子が特定 のサイズへと変換してゆくことを示している. 言い換えると, 反応時間を調節することで, 様々 なサイズの白金クラスターをサイズ選択的に合 成できることを示している。しかしながら，テ
トラオクチルアンモニウムブロミドを配位子に 用いた場合には，白金と配位子の結合が弱いた め, MALDI 質量分析を用いた場合においても， 解離を含んだピークとして観測されてしまう。 そのため, 白金クラスターの白金原子数を見積 もることは可能であるが，配位子の数を含めた 化学組成については, 決定することが困難で あった。

\section{2 フェニルエタンチオラート保護白金クラ スターの合成と評価}

私達は合成した白金クラスターの化学組成を 厳密に決定するために, 白金との結合が強固に なると期待されるフェニルエタンチオラートを 配位子に用いてクラスターを合成した，図6に， 反応時間 30 分にて合成したフェニルエタンチ オラート保護白金クラスターの MALDI 質量ス ペクトルを示す。テトラオクチルアンモニウム ブロミドを用いた場合とは異なり，スペクトル 中には, 非常に鋭い複数のピーク群が観測され た。これらのピークの間隔は全て, 白金原子お よび硫黄原子のピーク間隔と一致した。最も強 いイオン強度にて観測されたピークについて は, $\mathrm{Pt}_{54-57} \mathrm{~S}_{12-16}$ と帰属された。このことは, こ うしたサイズ領域の白金クラスターは, 白金 54-57 原子，硫黄 12-16 原子から構成されてい ることを示している。実際，チオラートによっ

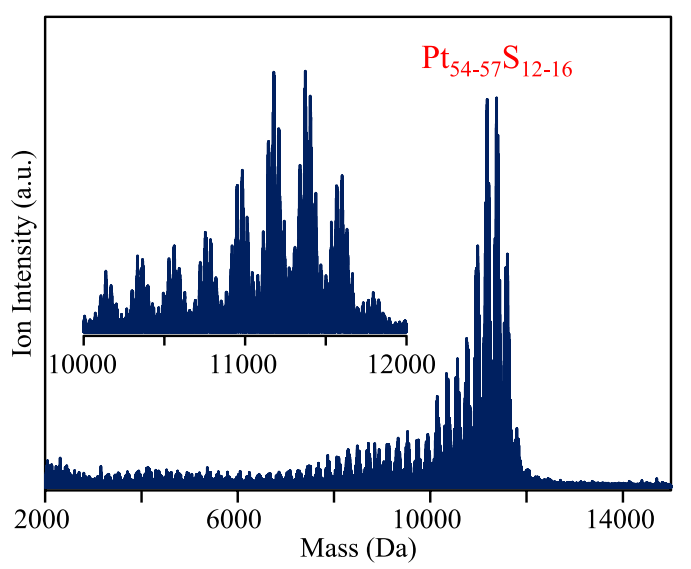

Figure 6 MALDI mass spectrum of phenylethane protected Pt cluster. 
て保護された白金 55 原子，硫黄 6-24 原子から 構成されるクラスターの存在が，理論的に予測 されている（Lee H. M. et al., 2011）。本実験に て合成した白金クラスターの白金原子数および 硫黄原子数は，これとよく一致していた。この ことは，理論計算によって予測されている白金 クラスターが, 化学的に合成された可能性を示 唆している。質量分析によるこうした精度での 白金クラスターの帰属については, 特殊な有機 配位子を用いた東工大のグループの報告 （Yamamoto K. et al., 2009）を除いて，私達の知 る限り初めての報告である。

\section{3 酸素還元触媒能の評価}

最後に，本研究にて合成した白金クラスター を用いて電極を作成し，白金クラスターの酸素 還元触媒能について調べた。図7に, Koutecky-Levich 式により求めた, 白金クラス ターおよび市販の白金ナノ粒子の質量活性を示 す。白金クラスターを用いることで，活性が約 1.5 倍程度向上することが分かった。これは， 同じ白金使用量で，約 1.5 倍程度の電流を取り 出すことが可能であることを強く示唆してい る。一方で,一粒子あたりの活性を計算すると， 白金クラスターの方が市販の白金ナノ粒子より も低いことが分かった. 白金クラスターおよび 市販の白金ナノ粒子を, バルクの白金と同じ fcc 構造を有していると仮定して表面原子数を 計算したところ，白金クラスターは市販の白金

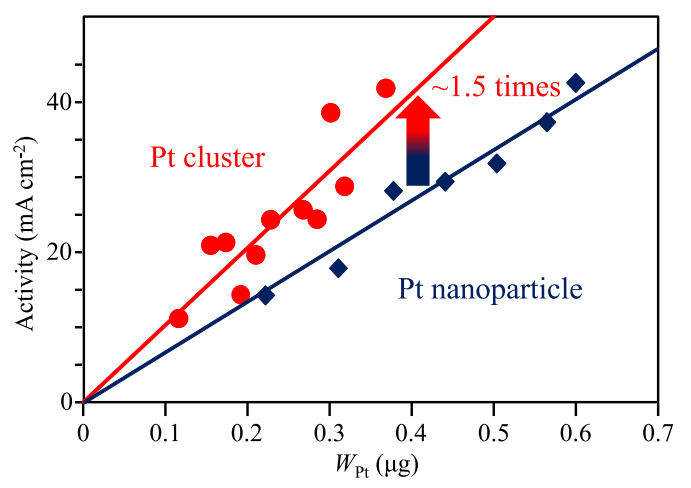

Figure 7 The comparison of activity.
ナノ粒子よりも 4 倍近い表面原子数をもつと見 積もられた（Negishi Y. et al., 2015）。しかしな がら，活性の増大は 1.5 倍程度であったことを 考慮に入れると, 粒径の微小化は, 必ずしも白 金クラスター自体の活性を向上させるわけでは ないことが示唆された。サイズの小さな白金ク ラスターの利用は，粒子自体の活性を低下させ るものの，同じ白金使用量で全体の反応表面積 を大きく増大させることが出来るため, 結果と して触媒活性は向上したと解釈される。

\section{参考文献}

[1] Dass A., Stevenson A., Dubay G. R., Tracy J. B., Murray R. W., Nanoparticle MALDI-TOF mass spectrometry without fragmentation: $\mathrm{Au}_{25}\left(\mathrm{SCH}_{2} \mathrm{CH}_{2} \mathrm{Ph}\right)_{18}$ and mixed monolayer $\mathrm{Au}_{25}\left(\mathrm{SCH}_{2} \mathrm{CH}_{2} \mathrm{Ph}\right)_{18-x}(\mathrm{~L})_{x}$, J. Am. Chem. Soc., 130 (2008) 5940-5946.

[2] Kurashige W., Munakata K., Nobusada K., Negishi Y., Synthesis of stable $\mathrm{Cu}_{n} \mathrm{Au}_{25-n}$ nanoclusters $(n=1-9)$ using selenolate ligands, Chem. Commun., 49 (2013), $5447-5449$

[3] Kurashige W., Niihori Y., Sharma S., Negishi Y., Recent progress in the functionalization methods of thiolateprotected gold clusters, J. Phys. Chem. Lett., 5, 2014, 4134-4142.

[4] Kurashige W., Yamaguchi M., Nobusada K., Negishi Y., Ligand-induced stability of gold nanoclusters: thiolate versus selenolate, J. Phys. Chem. Lett., 3 (2012) 2649 2652.

[5] Negishi Y., Igarashi K., Munakata K., Ohgake W., Nobusada K., Palladium doping of magic gold cluster $\mathrm{Au}_{38}\left(\mathrm{SC}_{2} \mathrm{H}_{4} \mathrm{Ph}\right)_{24}$ : formation of $\mathrm{Pd}_{2} \mathrm{Au}_{36}\left(\mathrm{SC}_{2} \mathrm{H}_{4} \mathrm{Ph}\right)_{24}$ with higher stability than $\mathrm{Au}_{38}\left(\mathrm{SC}_{2} \mathrm{H}_{4} \mathrm{Ph}\right)_{24}$, Chem. Commun., 48 (2012) 660-662.

[6] Negishi Y., Matsuura Y., Tomizawa R., Kurashige W., Niihori Y., Takayama T., Iwase A., Kudo A., Controlled loading of small $\mathrm{Au}_{n}$ Clusters $(n=10-39)$ onto $\mathrm{BaLa}_{4} \mathrm{Ti}_{4} \mathrm{O}_{15}$ photocatalysts: toward an understanding of size effect of co-catalyst on water splitting photocatalytic activity, J. Phys. Chem. C, 119 (2015) 11214-11232

[7] Qian H., Jiang D.-e., Li G., Gayathri C., Das A., Gil R. R., Jin R., Monoplatinum doping of gold nanoclusters and catalytic application, J. Am. Chem. Soc., 134 (2012) 16159-16162.

[8] Ryu J. H., Han S. S., Kim D. H., Henkelman G., Lee H. M., Ligand-induced structural evolution of $\mathrm{Pt}_{55}$ nanoparticles: amine versus thiol, ACS Nano., 5 (2011) 


\section{5-8522.}

[9] Wang Y., Ren J., Deng K., Gui L., Tang Y., Preparation of tractable platinum, rhodium, and ruthenium nanoclusters with small particle size in organic media, Chem. Mater., 12 (2000) 1622-1627.

外部発表成果

\section{論文発表}

1. Niihori Y., Kikuchi Y., Kato A., Matsuzaki M., Negishi Y., Understanding ligand-exchange reactions on thiolate-protected gold cluster by probing isomer distributions using reversedphase high-performance liquid chromatography, ACS Nano, 9 (2015) 9347-9356 (2015).

2. Sharma S., Kurashige W., Nobusada K., Negishi Y., Effect of trimetallization in thiolate-protected $\mathrm{Au}_{24-n} \mathrm{Cu}_{n} \mathrm{Pd}$ Clusters Nanoscale, 7 (2015) 10606-
[10] Yamamoto K., Imaoka T, Chun W. J., Enoki O., Katoh H., Takenaga M., Sonoi A., Size-specific catalytic activity of platinum clusters enhances oxygen reduction reactions, Nat. Chem., 1 (2009) 397-402.

10612.

3. Negishi Y., Nakazaki T., Malola S., Takano S., Niihori Y., Kurashige W., Yamazoe S., Tsukuda, T., Häkkinen H., A critical size for emergence of nonbulk electronic and geometric structures in dodecanethiolate-protected Au clusters, J. Am. Chem. Soc., 137 (2015) 1206-1212.

$$
\text { 口頭・ポスター発表 }
$$

1. Negishi Y., "Toward the Creation of Stable, Functionalized Metal Clusters", PACIFICHEM 2015 (Waikiki, USA, Dec.15-Dec.20, 2015). 